\title{
Particle Size, Surface Area, Crystallite Size, and Thermal Analysis of Consciousness Energy Healing Treated Selenium
}

\author{
Dahryn Trivedi ${ }^{1}$, Mahendra Kumar Trivedi $^{1}$, Alice Branton ${ }^{1}$, Gopal Nayak ${ }^{1}$ and Snehasis Jana ${ }^{2 *}$ \\ ${ }^{1}$ Trivedi Global, Inc., Henderson, USA \\ ${ }^{2}$ Trivedi Science Research Laboratory Pvt. Ltd., India
}

*Corresponding author: Snehasis Jana, Trivedi Science Research Laboratory Pvt. Ltd., India

Submission: November 21, 2018; Published: January 18, 2019

\begin{abstract}
Selenium (Se) is an essential micronutrient, which has various physiological functions and also required for the prevention and treatment of Se deficiency diseases. The objective of the research work was to evaluate the effect of the Trivedi Effect ${ }^{\circledR}$ on the physicochemical and thermal properties of Se powder using PSA, PXRD, and DSC analytical technique. The Se powder sample was divided into two parts. One part of Se was called as a control sample (no Biofield Energy Treatment was provided), while the second part received the Biofield Energy Treatment remotely by a famous Biofield Energy Healer, Dahryn Trivedi and termed as a treated sample. The particle size values of the treated Se powder were significantly decreased by $17.51 \%\left(\mathrm{~d}_{10}\right), 13.26 \%\left(\mathrm{~d}_{50}\right), 8.68 \%\left(\mathrm{~d}_{90}\right)$, and $11.24 \%\{\mathrm{D}(4,3)\}$; therefore, the specific surface area was significantly increased by $17.68 \%$ compared to the control sample. The Powder XRD peak intensities and crystallite sizes of the treated Se were significantly altered ranging from $-18.14 \%$ to $2.19 \%$ and $-4.3 \%$ to $14.29 \%$ respectively; however, the average crystallite size was increased by $1.54 \%$ compared with the control sample. The latent heat of fusion of the treated Se was significantly increased by $10.33 \%$ compared with the control sample. All results concluded that a new polymorphic form of Se might have generated after the Trivedi Effect ${ }^{\circledR}$-Consciousness Energy Healing Treatment which may be better soluble, bioavailable, and thermally more stable compared with the control sample. The Trivedi Effect ${ }^{\circledR}$ Treated selenium would be more efficacious nutraceutical and pharmaceutical formulations for the treatment of cancer, type-2 diabetes, cardiovascular disease, viral diseases, stress, aging, muscle disorders, male infertility, neurological disorders, degenerative ailments, etc.
\end{abstract}

Keywords: Selenium; Consciousness energy healing treatment; The Trivedi Effect ${ }^{\circledR}$; Particle size; Surface area; PXRD; DSC

\section{Introduction}

Selenium (Se) is an essential micronutrient for the animals aimed at various physiological functions, i.e., healthy metabolism and inhibition of the toxic effect of heavy metals in the body [1]. The food sources for Se are animal meat, fish, cereals, nuts, mushrooms and can be obtained from mineral supplements/multi-vitamins $[1,2]$. It is one of the key components of the active site of selenium enzymes, i.e., glutathione peroxidase, ribonucleotide reductase, etc. and about 30 selenoprotein (selenocysteine) [3]. The Se has potent antioxidant property, which protects from oxidative damage, also from infections, nervous system, plays critical roles in reproduction, DNA synthesis, and thyroid hormone metabolism $[1,4,5]$. The Se deficiency in the body responsible for the critical pathophysiology of several diseases, i.e., cancer, type-2 diabetes, viral diseases, male infertility, muscle disorders, cardiovascular disease, neurological disorders, degenerative ailments, etc. [6-8]. Poor selenium containing diet and genetic variations may lead to its deficiency in the body [9]. Low level of Se in the body may be responsible for many deficiency diseases, so it is recommended as a daily supplement in a number of countries. Though, the excess intake of Se may cause adverse health effects $[9,10]$. Se absorbs by the body in selenite form which is more than 80 percent. The physicochemical properties of any pharmaceutical/ nutraceutical compounds play a crucial role in its bioavailability in the body [11].

Worldwide pharmaceutical scientists doing extensive research on the improvement of the quality of pharmaceutical or nutraceutical compounds for better formulations. In this scenario, the Trivedi Effect $^{\circledR}$-Consciousness Energy Healing Treatment (Biofield Energy Healing Treatment) has the huge impact on the particle size, surface area, and thermal properties of pharmaceutical/nutraceutical compounds [12-15]. The Trivedi Effect ${ }^{\circledR}$ is a natural and only scientifically proven phenomenon in which a person can harness this inherently intelligent energy from the Universe and transmit it anywhere on the planet through the possible mediation of neutrinos [15]. Every living organism possesses this kind of unique, infinite, para-dimensional electromagnetic field surrounding the body, originate from the continuous movements of the charged particles, ions, cells, blood/lymph flow, brain functions, and heart function in the body known as the Biofield Energy. This Biofield Energy Therapy (energy medicine) have been reported to have substantial outcomes against various disease conditions $[15,16]$. The National Institutes 
of Health/National Center for Complementary and Alternative Medicine (NIH/NCCAM) recommend and included the Energy therapy under Complementary and Alternative Medicine (CAM) category along with homeopathy, traditional Chinese medicines, Ayurvedic medicine, acupuncture, acupressure, meditation, yoga Qi Gong, Tai Chi, chiropractic/osteopathic manipulation, Reiki, special diets, massage, relaxation techniques, movement therapy, hypnotherapy, pilates, Rolfing, mindfulness, cranial sacral therapy, aromatherapy, etc. The CAM therapies are well accepted by most of the U.S.A. people $[17,18]$. The Trivedi Effect ${ }^{\circledR}$-Consciousness Energy Healing Treatment also been scientifically reported with amazing results altering the characteristic properties of the several living and non-living object(s), i.e., metals and ceramic [19-21], organic compounds [22,23], microorganisms [24,25], cancer cells $[26,27]$ and crops $[28,29]$. The Biofield Energy Treatment has also improved the bioavailability of pharmaceutical and nutraceutical compounds [30,31]. Therefore, this experiment was designed to determine the impact of the Trivedi Effect ${ }^{\circledR}$-Consciousness Energy Healing Treatment on the physicochemical, and thermal properties of selenium using particle size analysis (PSA), powder X-ray diffraction (PXRD), and differential scanning calorimetry (DSC) analytical techniques.

\section{Materials and Methods}

\section{Chemicals and Reagents}

Selenium (Se) powder sample was procured from Sigma Aldrich, USA. All other chemicals required during the experiments were of the analytical standard available in India.

\section{Consciousness Energy Healing Treatment Strategies}

The test sample Se powder was divided into two parts. One part of the Se powder sample was treated with the Consciousness Energy Healing Treatment (the Trivedi Effect ${ }^{\circledR}$ ) remotely under standard laboratory conditions for 3 minutes and the sample was known as the Biofield Energy Treated sample. The Biofield Energy Treatment was provided by a renowned Biofield Energy Healer, Dahryn Trivedi, USA, to the test sample. Moreover, the other part of the powder sample was treated with a "sham" healer for comparison purpose. The "sham" healer completely ignorant about the Biofield Energy Treatment. After the treatment, the Biofield Energy Treated and control Se powder samples were kept in sealed conditions and characterized using modern analytical techniques.

\section{Characterization}

Particle Size Analysis (PSA): The particle size analysis of Se was performed with the help of Malvern Master sizer 2000, from the UK with a detection range between $0.01 \mu \mathrm{m}$ to $3000 \mu \mathrm{m}$ using the wet method $[32,33]$. The \% change in particle size (d) for Se powder at below 10\% level $\left(d_{10}\right) 50 \%$ level $\left(d_{50}\right) 90 \%$ level $\left(d_{90}\right)$ and $\mathrm{D}(4,3)$ was calculated using the following equation 1 :

$\%$ change in particle size $=\frac{\left[d_{\text {Treated }}-d_{\text {Control }]}\right.}{d_{\text {Control }}} \times 100$

Where $d_{\text {control }}$ and $d_{\text {Treated }}$ are the particle size $(\mu \mathrm{m})$ for at below $10 \%$ level $\left(d_{10}\right), 50 \%$ level $\left(d_{50}\right)$ and $90 \%$ level $\left(d_{90}\right)$ of the control and the Biofield Energy Treated samples, respectively.
The \% change in surface area $(\mathrm{S})$ was calculated using the following equation 2 :

$\%$ change in surface area $=\frac{\left[S_{\text {Treated }}-S_{\text {Control }]}\right.}{S_{\text {Control }}} \times 100$

Where $\mathrm{S}_{\text {Control }}$ and $\mathrm{S}_{\text {Treated }}$ are the surface area of the control and the Biofield Energy Treated Se, respectively.

Powder X-Ray Diffraction (PXRD) Analysis: The PXRD analysis of Se powder was executed with the help of Rigaku MiniFlex-II Desktop X-ray diffractometer (Japan) [34,35]. The size of individual crystallites was calculated from PXRD data using the Scherrer's formula (3):

$$
G=k \lambda / \beta \cos \theta
$$

Where $\mathrm{k}$ is the equipment constant (0.94), $\mathrm{G}$ is the crystallite size in $\mathrm{nm}, \lambda$ is the radiation wavelength $0.154056 \mathrm{~nm}$ for $\mathrm{K} \alpha 1$ emission), $\beta$ is the full-width at half maximum (FWHM), and $\theta$ is the Bragg angle [36].

The \% change in crystallite size (G) of Se was calculated using the following equation 4 :

$\%$ change in crystallite size $=\frac{\left[G_{\text {Treated }}-G_{\text {Control }]}\right.}{G_{\text {Control }}} \times 100$

Where $\mathrm{G}_{\text {Control }}$ and $\mathrm{G}_{\text {Treated }}$ are the crystallite size of the control and the Biofield Energy Treated samples, respectively.

Differential Scanning Calorimetry (DSC): The DSC analysis of Se powder was executed with the help of DSC Q200, TA instruments. Sample of $\sim 1-3 \mathrm{mg}$ was loaded to the aluminium sample pan at a heating rate of $10{ }^{\circ} \mathrm{C} / \mathrm{min}$ from $30{ }^{\circ} \mathrm{C}$ to $350{ }^{\circ} \mathrm{C}[32,33]$. The $\%$ change in melting point $(\mathrm{T})$ was calculated using the following equation 5 :

$$
\% \text { change in melting point }=\frac{\left[T_{\text {Treated }}-T_{\text {Control }]}\right.}{T_{\text {Control }}} \times 100
$$

Where $\mathrm{T}_{\text {Control }}$ and $\mathrm{T}_{\text {Treated }}$ are the melting point of the control and the Biofield Energy Treated samples, respectively.

The $\%$ change in the latent heat of fusion $(\Delta \mathrm{H})$ was calculated using the following equation 6 :

$\%$ change in the latent heat of fusion $=\frac{\left[\Delta H_{\text {Treated }}-\Delta H_{\text {Control }]}\right.}{\Delta H_{\text {Control }}} \times 100$

Where $\Delta \mathrm{H}_{\text {Control }}$ and $\Delta \mathrm{H}_{\text {Treated }}$ are the latent heat of fusion of the control and the Biofield Energy Treated Se, respectively.

\section{Results and Discussion}

\section{Particle Size Analysis (PSA)}

The particle size distribution data and surface area of both the control and the Biofield Energy Treated Se powder are presented in Table 1. The particle size values of the control Se powder at $\mathrm{d}_{10}, \mathrm{~d}_{50}, \mathrm{~d}_{90}$ and $\mathrm{D}(4,3)$ were $9.671 \mu \mathrm{m}, 26.003 \mu \mathrm{m}, 52.113 \mu \mathrm{m}$, and $28.787 \mu \mathrm{m}$, respectively. Likewise, the particle sizes of the Biofield Energy Treated sample at $\mathrm{d}_{10}, \mathrm{~d}_{50}, \mathrm{~d}_{90}$ and $\mathrm{D}(4,3)$ were $7.978 \mu \mathrm{m}$, $22.556 \mu \mathrm{m}, 47.591 \mu \mathrm{m}$ and $25.552 \mu \mathrm{m}$ respectively. Thus, the particle size values in Dahryn's Biofield Energy Treated sample were significantly decreased by $17.51 \%, 13.26 \%, 8.68 \%$, and $11.24 \%$ 
at $d_{10}, d_{50}, d_{90}$ and $D(4,3)$, respectively compared to the control sample. As a result, the specific surface area of the Biofield Energy Treated sample $\left(0.386 \mathrm{~m}^{2} / \mathrm{g}\right)$ was significantly increased by $17.68 \%$ compared with the control sample $\left(0.328 \mathrm{~m}^{2} / \mathrm{g}\right)$. Hence, it can be presumed that the Trivedi Effect ${ }^{\circledR}$ might act as an external force for breaking larger particles to smaller one hence increased the surface area of Se powder sample. As per the literature pharmaceutical compounds with reduced particle size increase the surface area and improve the solubility, dissolution rate, and bioavailability in the body [11,37]. Thus, it is anticipated that the Trivedi Effect ${ }^{\circledR}$ Treated Se powder would offer better solubility and bioavailability compared with the control sample.

Table 1: Particle size distribution of the control and the Biofield Energy Treated selenium.

\begin{tabular}{|c|c|c|c|c|c|}
\hline Parameter & $\mathbf{d}_{\mathbf{1 0}}(\boldsymbol{\mu} \mathbf{m})$ & $\mathbf{d}_{\mathbf{5 0}}(\boldsymbol{\mu} \mathbf{m})$ & $\mathbf{d}_{\mathbf{9 0}}(\mu \mathbf{m})$ & $\mathbf{D}(\mathbf{4 , 3})(\mu \mathbf{m})$ & $\mathbf{S S A}\left(\mathbf{m}^{2} / \mathbf{g}\right)$ \\
\hline Control & 9.671 & 26.003 & 52.113 & 28.787 & 0.328 \\
\hline Biofield Energy Treated & 7.978 & 22.556 & 47.591 & 25.552 & 0.386 \\
\hline Percent change* $(\%)$ & -17.51 & -13.26 & -8.68 & -11.24 & 17.68 \\
\hline
\end{tabular}

$d_{10}, d_{50}$ and $d_{90}$ : Particle diameter corresponding to $10 \%, 50 \%$ and $90 \%$ of the cumulative distribution, D (4,3): The average mass-volume diameter, and SSA: The specific surface area. *denotes the percentage change in the Particle size distribution of the Biofield Energy Treated sample with respect to the control sample.

\section{Powder X-Ray Diffraction (PXRD) Analysis}

The PXRD diffractograms of the control and the Biofield Energy Treated Se powder showed sharp and intense peaks (Figure 1) specified that both the samples were crystalline. The highest peak intensity of the control and the Biofield Energy Treated samples were observed at $2 \theta$ equal to $29.8^{\circ}$ in both the diffractograms (Table 2, entry 2). The peak intensities of the Biofield Energy Treated Se sample were significantly altered ranging from $-18.14 \%$ to $2.19 \%$ compared to the control sample. The crystallite sizes of the Biofield Energy Treated Se powder were significantly altered ranging from $-4.3 \%$ to $14.29 \%$ compared with the control sample. Overall, the average crystallite size of the Biofield Energy Treated Se powder $(99.71 \mathrm{~nm})$ was increased by $1.54 \%$ compared with the control sample $(98.2 \mathrm{~nm})$.

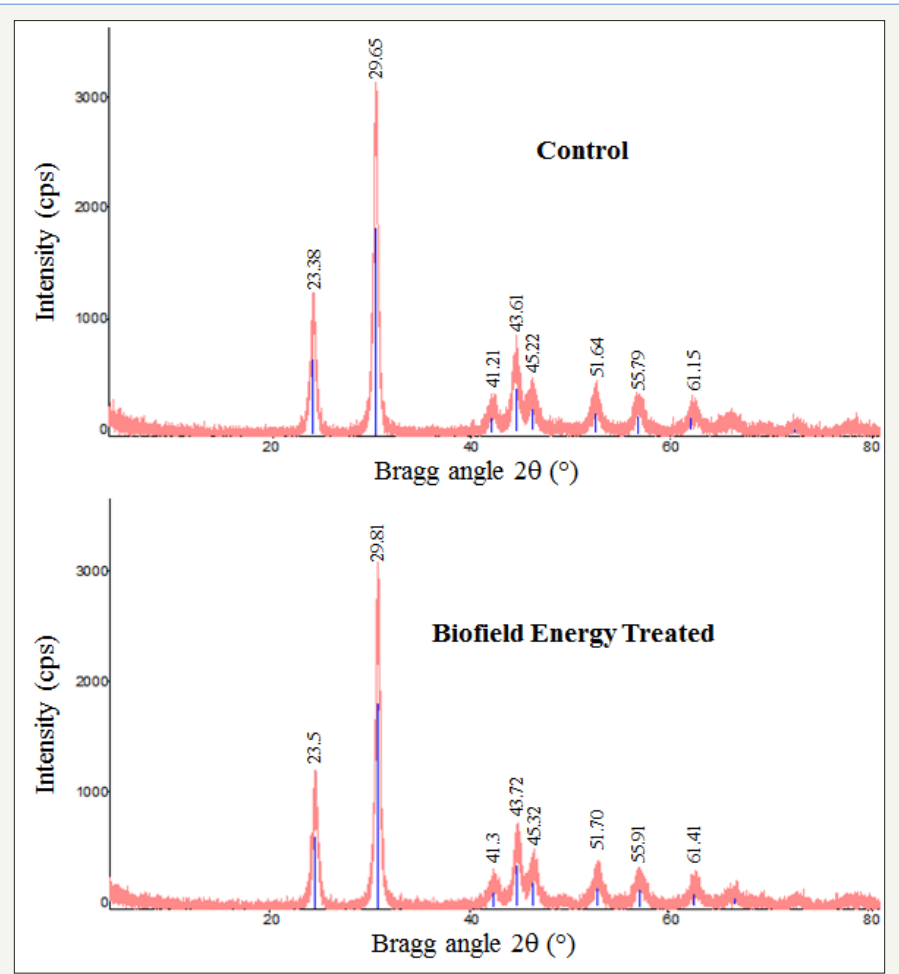

Figure 1: PXRD diffractograms of the control and the Biofield Energy Treated selenium.

Table 2: PXRD data for the control and the Biofield Energy Treated selenium.

\begin{tabular}{|c|c|c|c|c|c|c|c|c|}
\hline \multirow[b]{2}{*}{ Entry No. } & \multicolumn{2}{|c|}{ Bragg angle $\left({ }^{\circ} 2 \theta\right)$} & \multicolumn{3}{|c|}{ Peak Intensity (\%) } & \multicolumn{3}{|c|}{ Crystallite size $(\mathrm{G}, \mathrm{nm})$} \\
\hline & Control & Treated & Control & Treated & $\%$ change $^{a}$ & Control & Treated & $\%$ change $^{\mathrm{b}}$ \\
\hline 1 & 23.38 & 23.5 & 569 & 537 & -5.62 & 122.1 & 120.4 & -1.39 \\
\hline 2 & 29.65 & 29.81 & 1349 & 1301 & -3.56 & 146.5 & 155.3 & 6.01 \\
\hline
\end{tabular}




\begin{tabular}{|c|c|c|c|c|c|c|c|c|}
\hline 3 & 41.21 & 41.3 & 164 & 152 & -7.32 & 80 & 83 & 3.75 \\
\hline 4 & 43.61 & 43.72 & 373 & 360 & -3.49 & 102 & 103 & 0.98 \\
\hline 5 & 45.22 & 45.32 & 266 & 253 & -4.89 & 70 & 80 & 14.29 \\
\hline 6 & 51.64 & 51.7 & 226 & 185 & -18.14 & 87 & 85 & -2.3 \\
\hline 7 & 55.79 & 55.91 & 183 & 187 & 2.19 & 85 & 82 & -3.53 \\
\hline 8 & 61.15 & 61.41 & 135 & 130 & -3.7 & 93 & 89 & -4.3 \\
\hline 9 & \multicolumn{9}{|c|}{ Average crystallite size } & & 98.2 & 99.71 & 1.54 \\
\hline
\end{tabular}

${ }^{a}$ denotes the percentage change in the peak intensity of the Biofield Energy Treated sample with respect to the control sample; bdenotes the percentage change in the crystallite size of the Biofield Energy Treated sample with respect to the control sample.

The significant alterations in the crystallite sizes and peak intensities might have altered the crystal morphology of the Biofield Energy Treated Se powder compared to the control sample. Literature suggested that the peak intensity of each diffraction face on the crystalline compound changes according to the crystal morphology and alterations in the PXRD pattern provide the proof of polymorphic transitions [38-40]. The Trivedi Effect ${ }^{\circledR}$ Consciousness energy healing treatment probably produced the new polymorphic form of Se through the possible mediation of neutrino [15]. Different polymorphic forms of pharmaceuticals have the significant effects on the drug performance, such as

bioavailability, therapeutic efficacy, and toxicity, because of their physicochemical properties like melting point, energy, stability, and especially solubility, are different from the original form [41]. Therefore, it can be projected that the Trivedi Effect ${ }^{\circledR}$-Consciousness Energy Healing Treated Se would be better in designing novel pharmaceutical and nutraceutical formulations containing Se; that might offer better therapeutic response against cancer, type-2 diabetes, cardiovascular disease, viral diseases, stress, aging, muscle disorders, male infertility, neurological disorders, degenerative ailments, etc.

\section{Differential Scanning Calorimetry (DSC) Analysis}

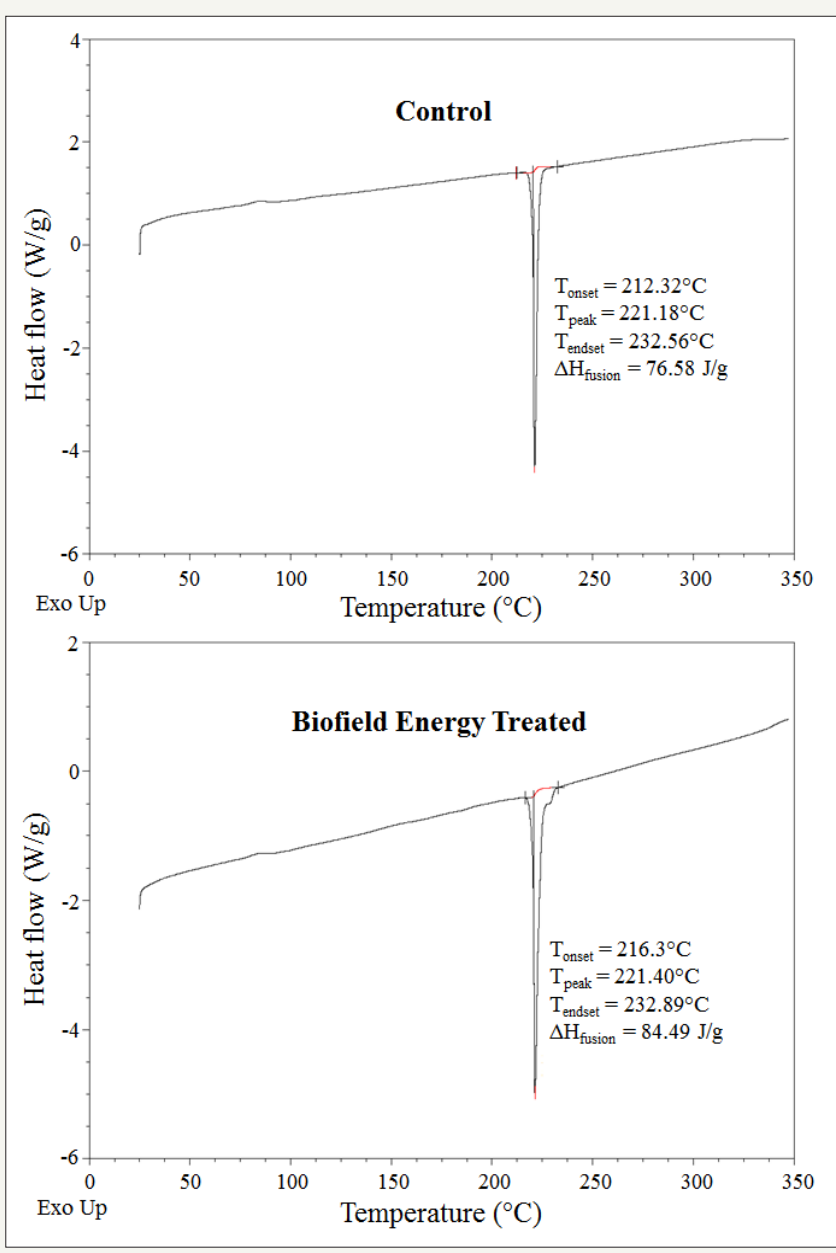

Figure 2: DSC thermograms of the control and the Biofield Energy Treated selenium. 
DSC analysis has been performed to characterize the thermal behavior of the Biofield Energy Treated Se compared to the control sample (Table 3). The DSC thermograms of the control and the Biofield Energy Treated sample showed the sharp endothermic peak at 221.18 and $221.4{ }^{\circ} \mathrm{C}$, respectively (Figure 2). The melting point of the Biofield Energy Treated Se sample was slightly increased by $0.1 \%$ compared with the control sample (Table 3 ). The latent heat of fusion $\left(\Delta \mathrm{H}_{\text {fusion }}\right)$ of the Biofield Energy Treated Se $(84.49 \mathrm{~J} / \mathrm{g})$ was significantly increased by $10.33 \%$ compared with the control sample (76.58J/g) (Table 3). The change in the melting point and latent heat of fusion can be attributed to the disrupted molecular chains and the crystal structure [42]. Thus, it can be assumed that Dahryn's consciousness energy healing treatment might be accountable for the stronger intermolecular chains and crystal structure of Se which the cause of improved thermal stability of the Biofield Energy Treated sample was compared with the control sample.

Table 3: DSC data for both control and the Biofield Energy Treated samples of selenium.

\begin{tabular}{|c|c|c|}
\hline Sample & Melting point $\left({ }^{\circ} \mathrm{C}\right)$ & $\mathbf{\Delta H}(\mathbf{J} / \mathbf{g})$ \\
\hline Control Sample & 221.18 & 76.58 \\
\hline Biofield Energy Treated & 221.4 & 84.49 \\
\hline \% Change* & 0.1 & 10.33 \\
\hline
\end{tabular}

$\Delta \mathrm{H}$ : Latent heat of fusion, *denotes the percentage change of the Biofield Energy Treated sample with respect to the control sample.

\section{Conclusion}

The Trivedi Effect ${ }^{\circledR}$-Consciousness Energy Healing Treatment showed a significant effect on the particle size, surface area, peak intensities, crystallite size, and thermal properties of Se powder. The particle size values of the Biofield Energy Treated Se powder were significantly decreased by $17.51 \%, 13.26 \%, 8.68 \%$, and $11.24 \%$ at $d_{10}, d_{50}, d_{90}$ and $D(4,3)$, respectively. Therefore, the specific surface area of the Biofield Energy Treated Se was significantly increased by $17.68 \%$ compared to the control sample. Significant reduction in particle sizes and increase in the surface area may help in improving the solubility and dissolution rate of the Biofield Energy Treated Se powder sample that further enhances its absorption and bioavailability profile within the physiological system. The PXRD analysis exhibited that the peak intensities of the Biofield Energy Treated Se were significantly altered in the range from $-18.14 \%$ to $2.19 \%$ compared with the control sample. Similarly, the crystallite sizes of the Biofield Energy Treated sample were significantly altered ranging from $-4.3 \%$ to $14.29 \%$ compared to the control sample. But, the average crystallite size of the Biofield Energy Treated Se was increased by $1.54 \%$ compared with the control sample. The $\Delta \mathrm{H}_{\text {fusion }}$ of the biofield energy treated Se was significantly increased by $10.33 \%$ compared with the control sample. The thermal analysis data showed improvement in the thermal stability of the Biofield Energy Treated Se compared to the control sample. Thus, the Trivedi Effect ${ }^{\circledR}{ }^{-}$-Consciousness Energy Healing Treatment might have generated a new polymorphic form of Se which may be better soluble, bioavailable, and thermally more stable compared with the control sample. The Trivedi Effect ${ }^{\circledR}$ Treated selenium would be more useful to design better nutraceutical and pharmaceutical formulations which would offer an enhanced therapeutic response against cancer, type- 2 diabetes, cardiovascular disease, viral diseases, stress, aging, muscle disorders, male infertility, neurological disorders, degenerative ailments, etc.

\section{Acknowledgement}

The authors are grateful to Central Leather Research Institute, SIPRA Lab. Ltd., Trivedi Science, Trivedi Global, Inc., Trivedi Testimonials, and Trivedi Master Wellness for their assistance and support during this work.

\section{References}

1. Dietary supplement fact sheet: Selenium. National Institutes of Health; Office of Dietary Supplements.

2. Margaret NIB, Allan MP, James D (1995) Selenium content of a range of UK food. J Food Compos Anal 8: 307-318.

3. Stadtman TC (1996) Selenocysteine. Annu Rev Biochem 65: 83-100.

4. Li X, Yin D, Yin J, Chen Q Wang R (2014) Dietary selenium protect against redox-mediated immune suppression induced by methylmercury exposure. Food Chem Toxicol 72: 169-177.

5. Yang X, Bao Y, Fu H, Li L, Ren T, et al. (2014) Selenium protects neonates against neurotoxicity from prenatal exposure to manganese. PloS One 9(1): e86611.

6. Rayman MP (2012) Selenium and human health. The Lancet 379(9822): 1256-1268.

7. Hatfield DL, Tsuji PA, Carlson BA, Gladyshev VN (2014) Selenium and selenocysteine: Roles in cancer, health, and development. Trends Biochem Sci 39(3): 112-120.

8. Roman M, Jitaru P, Barbante C (2014) Selenium biochemistry and its role for human health. Metallomics 6(1): 25-54.

9. Brenneisen P, Steinbrenner H, Sies H (2005) Selenium, oxidative stress, health aspects. Mol Aspects Med 26(4-5): 256-267.

10. Levander OA, Burk RF (2006) Update of human dietary standards for selenium. In: Hatfield DL, Berry MJ, Gladyshev VN, (Eds.), Selenium - Its molecular biology and role in human health, Springer, New York, USA.

11. Chereson R (2009) Bioavailability, bioequivalence, and drug selection. In: Makoid CM, Vuchetich PJ, Banakar UV (Eds.), Basic pharmacokinetics ( $1^{\text {st }}$ edn), Pharmaceutical Press, London.

12. Trivedi MK, Branton A, Trivedi D, Nayak G, Lee AC, et al. (2017) Investigation of physicochemical, spectral, and thermal properties of sodium selenate treated with the Energy of Consciousness (the Trivedi Effect $^{\circledR}$ ). American Journal of Life Sciences 5: 27-37.

13. Trivedi MK, Branton A, Trivedi D, Nayak G, Wellborn BD, et al. (2017) Characterization of physical, structural, thermal, and behavioral properties of the consciousness healing treated zinc chloride. World Journal of Applied Chemistry 2: 57-66.

14. Trivedi MK, Patil S, Shettigar H, Bairwa K, Jana S (2015) Effect of biofield treatment on spectral properties of paracetamol and piroxicam. Chem Sci J 6: 98.

15. Trivedi MK, Mohan TRR (2016) Biofield energy signals, energy transmission and neutrinos. American Journal of Modern Physics 5: 172-176.

16. Rubik B, Muehsam D, Hammerschlag R, Jain S (2015) Biofield science and healing: History, terminology, and concepts. Glob Adv Health Med 
$4: 8-14$.

17. Barnes PM, Bloom B, Nahin RL (2008) Complementary and alternative medicine use among adults and children: United States, 2007. Natl Health Stat Report 12: 1-23.

18. Koithan M (2009) Introducing complementary and alternative therapies. J Nurse Pract 5(1): 18-20.

19. Trivedi MK, Patil S, Tallapragada RM. Effect of biofield treatment on the physical and thermal characteristics of Silicon, Tin and Lead powders. J Material Sci Eng 2: 125.

20. Trivedi MK, Mohan R, Branton A, Trivedi D, Nayak G, et al. (2015) Evaluation of biofield energy treatment on physical and thermal characteristics of selenium powder. Journal of Food and Nutrition Sciences 3(6): 223-228.

21. Trivedi MK, Nayak G, Patil S, Tallapragada RM, Latiyal O (2015) Studies of the atomic and crystalline characteristics of ceramic oxide nano powders after bio field treatment. Ind Eng Manage 4: 161.

22. Trivedi MK, Branton A, Trivedi D, Nayak G, Sethi KK, et al. (2016) Evaluation of isotopic abundance ratio in biofield energy treated nitrophenol derivatives using gas chromatography-mass spectrometry. American Journal of Chemical Engineering 4: 68-77.

23. Trivedi MK, Branton A, Trivedi D, Nayak G, Panda P, et al. (2016) Determination of isotopic abundance of ${ }^{13} \mathrm{C} /{ }^{12} \mathrm{C}$ or ${ }^{2} \mathrm{H} /{ }^{1} \mathrm{H}$ and ${ }^{18} \mathrm{O} /{ }^{16} \mathrm{O}$ in biofield energy treated 1-chloro-3-nitrobenzene (3-CNB) using gas chromatography-mass spectrometry. Science Journal of Analytical Chemistry 4(4): 42-51.

24. Trivedi MK, Branton A, Trivedi D, Shettigar H, Nayak G, et al. (2015) Antibiogram, biochemical reactions and genotyping characterization of biofield treated Staphylococcus aureus. American Journal of Bio Science 3(6): 212-220.

25. Trivedi MK, Branton A, Trivedi D, Nayak G, Mondal SC, et al. (2015) Antimicrobial sensitivity, biochemical characteristics and biotyping of Staphylococcus saprophyticus: An impact of biofield energy treatment. J Women's Health Care 4: 271.

26. Trivedi MK, Patil S, Shettigar H, Mondal SC, Jana S (2015) The potential impact of biofield treatment on human brain tumor cells: A time-lapse video microscopy. J Integr Oncol 4: 141.

27. Trivedi MK, Patil S, Shettigar H, Gangwar M, Jana S (2015) In vitro evaluation of biofield treatment on cancer biomarkers involved in endometrial and prostate cancer cell lines. J Cancer Sci Ther 7: 253-257.

28. Trivedi MK, Branton A, Trivedi D, Nayak G, Mondal SC, et al. (2015) Evaluation of plant growth, yield and yield attributes of biofield energy treated Mustard (Brassica juncea) and Chick pea (Cicer arietinum) Seeds. Agriculture, Forestry and Fisheries 4: 291-295.

29. Trivedi MK, Branton A, Trivedi D, Nayak G, Gangwar M, et al. (2015) Evaluation of vegetative growth parameters in biofield treated bottle gourd (Lagenaria siceraria) and Okra (Abelmoschus esculentus). International Journal of Nutrition and Food Sciences 4(6): 688-694.

30. Branton A, Jana S (2017) Effect of the biofield energy healing treatment on the pharmacokinetics of 25-hydroxyvitamin $\mathrm{D}_{3}\left[25(\mathrm{OH}) \mathrm{D}_{3}\right]$ in rats after a single oral dose of vitamin $\mathrm{D}_{3}$. American Journal of Pharmacology and Phytotherapy 2(1): 11-18.

31. Branton A, Jana S (2017) The use of novel and unique biofield energy healing treatment for the improvement of poorly bioavailable compound, berberine in male Sprague Dawley rats. American Journal of Clinical and Experimental Medicine 5(4): 138-144.

32. Trivedi MK, Sethi KK, Panda P, Jana S (2017) A comprehensive physicochemical, thermal, and spectroscopic characterization of zinc (II) chloride using X-ray diffraction, particle size distribution, differential scanning calorimetry, thermogravimetric analysis/ differential thermogravimetric analysis, ultraviolet-visible, and Fourier transform-infrared spectroscopy. Int J Pharm Investig 7(1): 33-40.

33. Trivedi MK, Sethi KK, Panda P, Jana S (2017) Physicochemical, thermal and spectroscopic characterization of sodium selenate using XRD, PSD, DSC, TGA/DTG, UV-vis, and FT-IR. Marmara Pharmaceutical Journal 21(2): 311-318.

34. Desktop X-ray Diffractometer (1997) Mini Flex. The Rigaku Journal 14: 29-36.

35. Zhang T, Paluch K, Scalabrino G, Frankish N, Healy AM, et al. (2015) Molecular structure studies of (1S,2S)-2-benzyl-2,3-dihydro-2(1Hinden-2-yl)-1H-inden-1-ol. J Mol Struct 1083: 286-299.

36. Langford JI, Wilson AJC (1978) Scherrer after sixty years: A survey and some new results in the determination of crystallite size. J Appl Cryst 11: 102-113.

37. Zhao Z, Xie M, Li Y, Chen A, Li G, et al. (2015) Formation of curcumin nanoparticles via solution-enhanced dispersion by supercritical $\mathrm{CO}_{2}$. Int J Nanomedicine 10: 3171-3181.

38. Inoue M, Hirasawa I (2013) The relationship between crystal morphology and XRD peak intensity on $\mathrm{CaSO}_{4} \cdot 2 \mathrm{H}_{2} \mathrm{O}$. J Crystal Growth 380: 169-175.

39. Raza K, Kumar P, Ratan S, Malik R, Arora S (2014) Polymorphism: The phenomenon affecting the performance of drugs. SOJ Pharm Pharm Sci $1: 10$.

40. Brittain HG (2009) Polymorphism in pharmaceutical solids in drugs and pharmaceutical sciences, volume 192, $\left(2^{\text {nd }}\right.$ edn), Informa Healthcare, New York, USA.

41. Censi R, Martino PD (2015) Polymorph Impact on the bioavailability and stability of poorly soluble drugs. Molecules 20(10): 18759-18776.

42. Blagden N, De Matas M, Gavan PT, York P (2007) Crystal engineering of active pharmaceutical ingredients to improve solubility and dissolution rates. Adv Drug Deliv Rev 59(7): 617-630.
Creative Commons Attribution 4.0 International License

For possible submissions Click Here

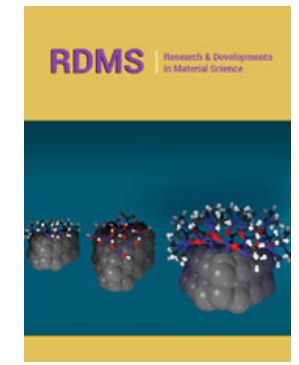

\section{Research \& Development in Material Science}

\section{Benefits of Publishing with us}

- High-level peer review and editorial services

- Freely accessible online immediately upon publication

- Authors retain the copyright to their work

- Licensing it under a Creative Commons license

- Visibility through different online platforms 